\title{
Behavioral characterization of mice lacking Trek channels
}

\author{
Kelsey Mirkovic ${ }^{1}$, Jaime Palmersheim ${ }^{1}$, Florian Lesage ${ }^{2}$ and Kevin Wickman ${ }^{1 *}$ \\ ${ }^{1}$ Department of Pharmacology, University of Minnesota, Minneapolis, MN, USA \\ ${ }^{2}$ Institut de Pharmacologie Moléculaire et Cellulaire Labex ICST, Université de Nice Sophia Antipolis, Valbonne, France
}

\section{Edited by:}

Inga D. Neumann, University of

Regensburg, Germany

Reviewed by:

Randy J. Nelson, The Ohio State University, USA

Mathias V. Schmidt, Max Planck

Institute of Psychiatry, Germany

\section{*Correspondence:}

Kevin Wickman, Department of

Pharmacology, University of

Minnesota, 6-120 Jackson Hall,

321 Church Street S.E. Minneapolis,

MN 55455, USA.

e-mail:wickm002@umn.edu
Two-pore domain $\mathrm{K}^{+}\left(\mathrm{K}_{2 \mathrm{P}}\right)$ channels are thought to underlie background $\mathrm{K}^{+}$conductance in many cell types. The Trek subfamily of $K_{2 P}$ channels consists of three members, Trek1/Kcnk2, Trek2/Kcnk10, and Traak/Kcnk4, all three of which are expressed in the rodent CNS. Constitutive ablation of the Trek 1 gene in mice correlates with enhanced sensitivity to ischemia and epilepsy, decreased sensitivity to the effects of inhaled anesthetics, increased sensitivity to thermal and mechanical pain, and resistance to depression. While the distribution of Trek2 mRNA in the CNS is broad, little is known about the relevance of this Trek family member to neurobiology and behavior. Here, we probed the effect of constitutive Trek 2 ablation, as well as the simultaneous constitutive ablation of all three Trek family genes, in paradigms that assess motor activity, coordination, anxiety-related behavior, learning and memory, and drug-induced reward-related behavior. No differences were observed between Trek2 $2^{-/-}$and Trek1/2/Traak ${ }^{-/-}$mice in coordination or total distance traveled in an open-field. A gender-dependent impact of Trek ablation on open-field anxiety-related behavior was observed, as female but not male Trek2-/- and Trek 1/2/Traak ${ }^{-/-}$mice spent more time in, and made a greater number of entries into, the center of the open-field than wild-type counterparts. Further evaluation of anxiety-related behavior in the elevated plus maze and light/dark box, however, did not reveal a significant influence of genotype on performance for either gender. Furthermore, Tre $k^{-1-}$ mice behaved normally in tests of learning and memory, including contextual fear conditioning and novel object recognition, and with respect to opioid-induced motor stimulation and conditioned place preference (CPP). Collectively, these data argue that despite their broad distribution in the CNS, Trek channels exert a minimal influence on a wide-range of behaviors.

Keywords: knockout, potassium channel, behavior, morphine, anxiety, memory

\section{INTRODUCTION}

Two-pore domain $\mathrm{K}^{+}\left(\mathrm{K}_{2 \mathrm{P}}\right)$ channels are thought to underlie the background $\mathrm{K}^{+}$conductance in many cell types (Enyedi and Czirjak, 2010). The $\mathrm{K}_{2 \mathrm{P}}$ channel family is diverse, with six subfamilies containing members that differ primarily in terms of biophysical properties and regulation (Enyedi and Czirjak, 2010). The Trek subfamily of $\mathrm{K}_{2 \mathrm{P}}$ channels consists of three membersTrek1/Kcnk2, Trek2/Kcnk10, and the more distantly-related member, Traak/Kcnk4. Trek1 and Trek2 channel activity is regulated by a diverse set of stimuli including arachidonic acid (Patel et al., 1998; Lesage et al., 2000; Maingret et al., 2000), membrane stretch (Patel et al., 1998; Bang et al., 2000; Lesage et al., 2000), intracellular acidification (Maingret et al., 1999; Lesage et al., 2000; Kim et al., 2001), and heat (Maingret et al., 2000; Kang et al., 2005). Additionally, both Trek1 and Trek 2 channels are inhibited by protein kinase $\mathrm{A}$ (PKA) and protein kinase $\mathrm{C}$ (PKC) phosphorylation, which couples these channels to $G_{s}, G_{i / o}$, and $G_{q} G$ protein signaling cascades (Fink et al., 1996; Patel et al., 1998; Lesage et al., 2000; Maingret et al., 2000; Bockenhauer et al., 2001; Murbartian et al., 2005).

In situ hybridization revealed a broad distribution of Trek1 in the rat CNS (Talley et al., 2001; Gu et al., 2002), and genetic ablation of Trek1 correlates with multiple neurophysiological and neurobehavioral phenotypes. Trek $1^{-/-}$mice are more sensitive to ischemia and epilepsy, show lower sensitivity to the effects of inhaled anesthetics, and display an increased sensitivity to thermal and mechanical pain (Heurteaux et al., 2004; Alloui et al., 2006; Noel et al., 2009). Trek1-/- mice also exhibit a depressionresistant phenotype, suggesting that Trek1-containing channels are a potential downstream target of selective serotonin reuptake inhibitors (SSRIs). Indeed, these drugs had no effect on Trek $1^{-/-}$ mice (Heurteaux et al., 2006). Accordingly, Trek1 represents a potential target for novel therapeutic strategies to combat depression (Perlis et al., 2008; Liou et al., 2009; Mazella et al., 2010; Moha ou Maati et al., 2011; Moha Ou Maati et al., 2012).

Compared with Trek1, relatively little is known about the neurobiological relevance of Trek2. An early study described a limited CNS distribution of Trek2 (Talley et al., 2001). Other evidence, however, including results from human tissue PCR, in situ hybridization from zebrafish, and rat in situ hybridization data suggest that Trek2 is expressed broadly throughout the CNS (Medhurst et al., 2001; Gu et al., 2002; Gierten et al., 2012). Moreover, we reported recently using a cDNA panel that Trek2 mRNA is expressed in most regions of the mouse brain (Mirkovic 
and Wickman, 2011). These observations suggest that Trek2 may make a broad and significant contribution to neurophysiology and behavior.

While RNAi-dependent knockdown of Trek2 in the entorhinal cortex was shown to disrupt spatial memory (Deng et al., 2009), data concerning the neurobehavioral relevance of Trek 2 are scant. The recent development of mice lacking Trek2 (Trek2 $\left.{ }^{-/-}\right)$and all three members of the Trek channel family (Trek1/2/Traak $\left.{ }^{-/-}\right)$, however, permit rigorous testing of the role of Trek channels, and Trek2-containing channels in particular, in behavior (Heurteaux et al., 2004; Guyon et al., 2009). In this study, we probe the consequences of constitutive Trek gene ablation in mice, in paradigms that assess motor activity, coordination, anxiety-related behavior, learning and memory, and drug-induced reward-related behavior.

\section{MATERIALS AND METHODS EXPERIMENTAL SUBJECTS}

All animal use was approved by the University of Minnesota Institutional Animal Care and Use Committee and carried out in accordance with National Institutes of Health guidelines. All mice used in this study were bred on-site, housed in same-sex groups of 2-5 after weaning, and provided with food and water ad libitum. Mice were kept on a $12 \mathrm{~h}$ light/dark cycle, with lights on between 0700 and 1900. All tests were performed between 0900 and 1600. Mice lacking Trek2 (Trek2 ${ }^{-/-}$) and mice lacking Trek1, Trek2, and Traak (Trek1/2/Traak ${ }^{-/-}$) were generated as described (Heurteaux et al., 2004; Guyon et al., 2009). Null mutations were backcrossed against the C57BL/6J inbred strain for $10+$ generations prior to establishing the breeding cages used to generate subjects for this study. Both male and female mice (5-10 weeks) were evaluated in all behavioral tests. No more than three distinct behavioral tests were performed on any single animal, and in no instance were animals evaluated in any test after completing the morphine-induced motor activity, conditioned place preference (CPP) studies, or the contextual fear conditioning test.

\section{LOCOMOTOR ACTIVITY}

One day prior to locomotor activity assessments, mice were habituated to handling $(5 \mathrm{~min})$ and testing room $(60 \mathrm{~min})$. On the first day of testing, mice were placed in open-field activity chambers (ENV-515; Med Associates, Inc.; St. Albans, VT), housed within sound-attenuating cubicles for $60 \mathrm{~min}$. The open-field was illuminated with $28 \mathrm{~V}$ DC/100 mA house lights (ENV-215 M; Med Associates, Inc.) during testing. Total distance traveled, thigmotaxis, and time/entries into the central area of the open-field were recorded using Open Field Activity Software package v. 4.0 (Med Associates, Inc.). For the morphine-induced motor activity study, total distance traveled was measured for $60 \mathrm{~min}$, beginning $10 \mathrm{~min}$ after an intraperitoneal (i.p.) injection of morphine (Sigma; St Louis, MO). Each mouse received all morphine doses, with three rest days between injections.

\section{ROTAROD}

Motor coordination was assessed using an accelerating rotarod (IITC Life Sciences; Woodland Hills, CA), as described (Anderson et al., 2010). Briefly, mice were acclimated to the testing room $1 \mathrm{~h}$ prior to evaluation. Each subject was given two trials to acclimate to the task, followed by 6-test trial. Animals were allowed a minimum of $15 \mathrm{~min}$ to rest between trials, followed by a $2 \mathrm{~h}$ break after trial 4. After placement of the subject on the rod, the rod was accelerated from 4 to $27 \mathrm{rpm}$ over a $5 \mathrm{~min}$ period. Latency to fall was recorded when a subject fell from the rod, or made 2 full revolutions while clinging to the drum.

\section{ELEVATED PLUS MAZE}

Anxiety-related behavior was measured using the elevated plus maze, as described (Pravetoni and Wickman, 2008). In brief, mice were acclimated to the testing room $1 \mathrm{~h}$ prior to evaluation. The maze consisted of two open and two closed arms, as well as an exposed center panel, elevated $52 \mathrm{~cm}$ off the floor of the testing room (Columbus Instruments, Inc.; Columbus, $\mathrm{OH}$ ). Testing was conducted under standard room lighting conditions. Each trial began with the placement of the mouse in the maze center, facing a closed arm; subsequent activity was recorded by video camera for $5 \mathrm{~min}$. The time spent by each mouse in the open and closed arms was scored manually by two investigators blind to subject genotype. Time spent in the EPM center was not included as time in either open or closed arms.

\section{LIGHT/DARK BOX}

The light/dark test was performed in a modified twocompartment mouse CPP chamber (Env-3013-2; Med Associates, Inc.) housed in a sound-attenuating cubicle. Flooring was normalized in both compartments using plexiglass inserts. The overhead light was turned off in the black chamber (dark), while the white (light) chamber was illuminated by a $28 \mathrm{~V} \mathrm{DC} / 100 \mathrm{~mA}$ light bulb (ENV-221M; Med Associates, Inc.) connected to a 3channel light control unit (ENV-226B; Med Associates, Inc.) set at intensity level 10. Mice were acclimated to the testing room for 30 min before testing. The mouse was placed in the center of the black chamber and allowed full access to both compartments after a $5 \mathrm{~s}$ delay. Time spent and distance traveled in both compartments was recorded during a $10 \mathrm{~min}$ trial using Med-PC software (Med Associates, Inc.).

\section{CONTEXTUAL FEAR CONDITIONING}

Contextual fear conditioning was conducted in $30.5 \times 24.1 \times$ $21.0 \mathrm{~cm}$ conditioning chambers (VFC_008; Med Associates, Inc.), housed in a sound-attenuating cubicle, utilizing steel bar flooring connected to a shock generator. The chamber was illuminated using a combination infrared and visual overhead light box (NIR100; Med Associates, Inc.). Mice were allowed to acclimate to the testing room for $30 \mathrm{~min}$ prior to testing. Training consisted of $120 \mathrm{~s}$ baseline exposure followed by three conditioning trials. Each conditioning trial consisted of a 20 s light cue (ENV-229M; Med Associates, Inc.), a $20 \mathrm{~s}$ latency period, and a $2 \mathrm{~s}$ shock $(0.7 \mathrm{~mA})$, with an inter-trial interval of $60 \mathrm{~s}$. A 5 min test session was conducted $24 \mathrm{~h}$ later, where time spent freezing and number of freezing episodes were recorded using "Video freeze" software (Med Associates, Inc.).

\section{NOVEL OBJECT RECOGNITION}

The novel object recognition study was performed using openfield environments (ENV-022MD; Med Associates, Inc.), housed 
within sound-attenuating cubicles, and illuminated with $28 \mathrm{~V}$ DC/100 mA house lights (ENV-215M; Med Associates, Inc.). On Day 1, mice were handled and habituated to the open field environment for $60 \mathrm{~min}$. On Day 2, mice were evaluated over four sessions, separated by $10 \mathrm{~min}$ breaks, during which subjects were returned to their home cages. In Session 1 , animals were allowed to explore the open-field environment for $30 \mathrm{~min}$. In Sessions 2 and 3, mice were re-introduced to the open-field environment for $10 \mathrm{~min}$, and in both sessions the environments contained two identical objects (familiar). In Session 4, mice were re-introduced to the open-field environment for $5 \mathrm{~min}$, now containing one familiar and one novel object. Session 4 was videotaped and the time subjects spent interacting with each object was recorded manually. A subject was considered to be interacting with an object if its nose was directed toward (and within $2 \mathrm{~cm}$ of) the object. Objects used in this study were a single red Duplo (The LEGO Group; Enfield, CT) and a blue cap from a $50 \mathrm{~mL}$ conical tube. Objects were counter-balanced to account for any object preference effects.

\section{CONDITIONED PLACE PREFERENCE}

CPP was performed in two-compartment mouse CPP chambers (Env-3013-2; Med Associates, Inc.), housed within soundattenuating cubicles. One compartment contained white walls and a mesh floor, and the other contained black walls and a rod floor. The overhead light was identical in both chambers: a $28 \mathrm{~V}$ DC/100 mA light (ENV-221M; Med Associates, Inc.) connected to a 3-channel light control unit (ENV-226B; Med Associates, Inc.) set at intensity level 8 . All subjects were acclimated to handling (5 $\mathrm{min}$ ) and the testing room (1 h) for $2-3 \mathrm{~d}$ prior to beginning the 5-day test. On Day 1, mice were placed in the chamber for $15 \mathrm{~min}$ with the door separating compartments open; time spent in each compartment was recorded. Subjects spending more than $65 \%$ of their time in either compartment on Day 1 were excluded from the study. On Days 2-4, mice were subjected to two 20-min conditioning sessions, one in the morning (0900-1100) and one in the afternoon (1400-1600). In the morning session, mice were given a subcutaneous (s.c.) saline injection and confined to the compartment that was preferred on Day 1. In the afternoon sessions, mice were given s.c. morphine and confined to the opposite compartment. On Day 5, mice were placed in the chamber for $15 \mathrm{~min}$ with the door separating the compartments open; time spent in each compartment was then recorded during a 15 min test session using Med-PC software. The change in time spent on the drug-paired side as measured on Day 1 and Day 5 (Day 5-Day 1) was taken as the measure of morphine-induced CPP.

\section{STATISTICAL ANALYSIS}

Data are expressed throughout as mean \pm SEM and were analyzed using Sigma Plot 11.0 (Systat Software Inc.; Chicago, IL) or Prism v. 11 (GraphPad Software Inc.; La Jolla, CA). The potential impact of gender on performance in each task was assessed with two-way ANOVA for all tasks except rotarod, morphine-induced locomotor activation, and CPP, where a 3-way ANOVA was used. If the results of statistical analysis revealed no significant impact of gender on task performance, data from male and female subjects were pooled to increase the power of the analysis. Open field activity, elevated plus maze, light/dark box, contextual fear conditioning, and novel object recognition data were analyzed using one-way ANOVA; the Newman Keuls post hoc test was used when a significant interaction was found. For rotarod and morphineinduced motor activity data, a two-way ANOVA with repeated measures was used. Data from the morphine-induced CPP study was analyzed using a standard two-way ANOVA. Differences were considered significant if $P<0.05$.

\section{RESULTS}

The main goal of this study was to evaluate wild-type C57BL/6J and congenic Trek $2^{-/-}$mice in tests of motor activity, coordination, anxiety, learning and memory, and reward-related behavior. Congenic mice lacking all three members of the Trek subfamily (Trek1/2/Traak ${ }^{-/-}$mice) were evaluated in parallel, as up-regulation of Trek1 and/or Traak might compensate for the loss of Trek2 and suppress neurobehavioral phenotypes. Prior to testing, we profiled Trek $2^{-/-}$and Trek1/2/Traak ${ }^{-/-}$mice for gross deficiencies in sensory perception that might influence performance in the chosen behavioral tests. Trek2 $2^{-/-}$and Trek1/2/Traak ${ }^{-/-}$mice were indistinguishable from wild-type counterparts by all visual criteria, and they responded normally, without excessive vocalization, to gentle prodding and handling. No genotype-dependent differences in body weight were observed (not shown). Following acclimation to a dark room, Trek $2^{-/-}$and Trek1/2/Traak ${ }^{-1-}$ mice exhibited a normal pupil response (constriction) to a bright light. Trek $2^{-/-}$ and Trek1/2/Traak ${ }^{-/-}$mice also exhibited normal forepaw extension upon lowering to their home cage or benchtop, indicative of intact vision and normal depth perception. Trek $2^{-/-}$ and Trek1/2/Traak ${ }^{-/-}$mice exhibited normal responses to sudden sounds (clapping), arguing against gross deficits in hearing. Thus, no obvious developmental abnormalities, or deficits in touch, vision, or hearing, were evident in Trek $2^{-/-}$and Trek1/2/Traak ${ }^{-/-}$mice.

\section{MOTOR ACTIVITY AND COORDINATION}

Wild-type, Trek2 $2^{-/-}$and Trek1/2/Traak ${ }^{-/-}$mice were monitored for $60 \mathrm{~min}$ in open-field activity chambers for distance traveled and position within the field. Because we observed an influence of gender on time spent in and entries into the center of the open-field, all open-field activity data for male and female subjects were analyzed separately. No genotype-dependent differences were observed in male or female mice with respect to total distance traveled (Figure 1A) or velocity (Figure 1B). In male mice, no genotype-dependent differences were detected with respect to thigmotaxis (calculated as the ratio of distance traveled in the field periphery to total distance traveled), time spent in the center of the open-field, or number of entries into the center of the open-field (Figures 1C-E). In female mice, however, both Trek2 $2^{-/-}$and Trek1/2/Traak ${ }^{-/-}$mice showed less thigmotaxis (Figure 1C). Female Trek $2^{-/-}$and Trek1/2/Traak ${ }^{-/-}$mice also spent more time than wild-type controls in the field center (Figure 1D), and exhibited significantly more entries into the center as compared to wild-type female controls (Figure 1E), 


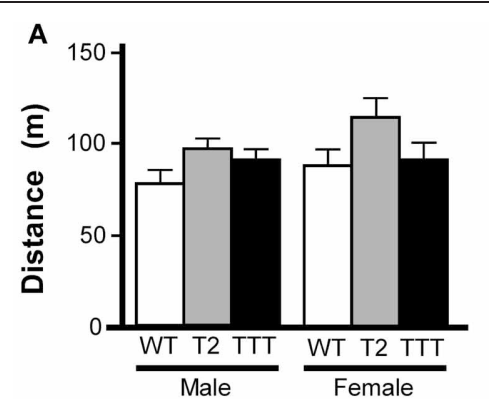

D

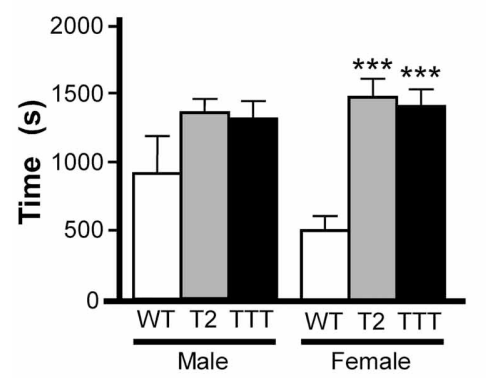

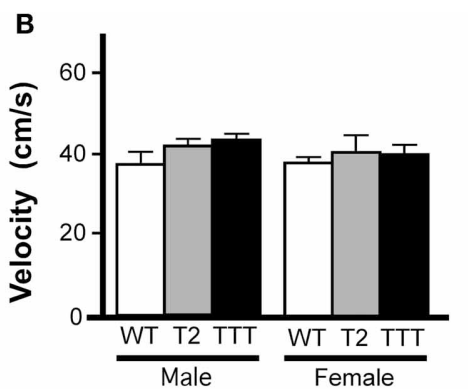

E

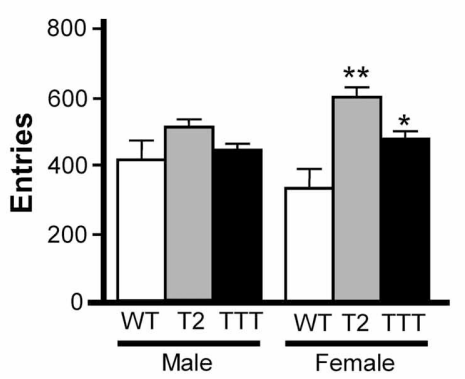

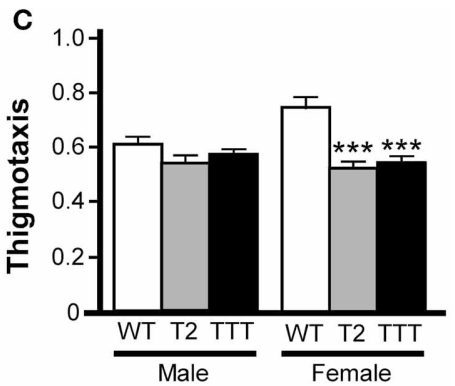

$\mathbf{F}$

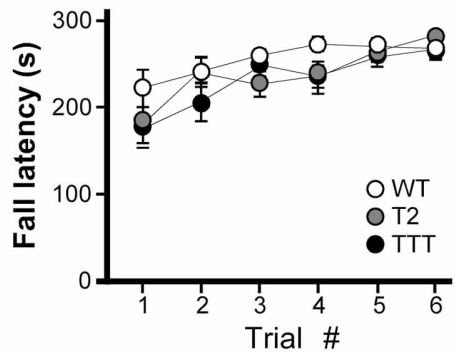

FIGURE 1 | Motor activity and coordination in mice lacking Trek channels. Open-field activity was measured in wild-type (WT, white), Trek2-1- (T2, gray), and Trek1/2/Traak-/- (TTT, black) mice during a 60 min test session ( $n=8-12$ per group). (A) Total distance traveled during the $60 \mathrm{~min}$ session. No genotype-dependent differences were observed between male $\left[F_{(2,29)}=2.3, P=0.12\right]$ or female $\left[F_{(2,30)}=1.9\right.$, $P=0.17]$ Trek2 $^{-/}$, Trek1/2/Traak ${ }^{-/}$, and wild-type mice. (B) Velocity during open-field activity; no genotype-dependent differences were observed between male $\left[F_{(2,29)}=2.1, P=0.14\right]$ or female $\left[F_{(2,30)}=0.3\right.$, $P=0.78]$ Trek2 $^{-/-}$, Trek1/2/Traak ${ }^{-/-}$, and wild-type mice.

(C) Thigmotaxis scores (distance traveled in periphery/total distance traveled); no genotype-dependent differences were observed in male animals $\left[F_{(2,29)}=2.2, P=0.13\right]$, whereas both Trek2 ${ }^{-/-}$and Trek1/2/Traak ${ }^{-/-}$females traveled less distance in the field periphery than wild-type controls $\left[F_{(2,30)}=11.0, P<0.001\right]$. (D) Time spent in the center of the open-field; a mild genotype-dependent difference was observed for male animals $\left[F_{(2,29)}=3.4, P<0.05\right]$, though post hoc pairwise comparisons did not reveal a difference between Trek2-/-, Trek1/2/Traak-/-, and wild-type controls. Trek2-/- and Trek1/2/Traak-1females spent significantly more time in the center than wild-type controls $\left[F_{(2,30)}=18.7, P<0.0001\right]$. (E) Number of entries into center of the open-field; no genotype-dependent differences were observed in male animals $\left[F_{(2,29)}=2.1, P=0.14\right]$, whereas both Trek2 ${ }^{-1-}$ and Trek1/2/Traak ${ }^{-/-}$females made more entries into the center than wild-type controls $\left[F_{(2,30)}=7.7, P<0.01\right]$. (F) Rotarod performance of wild-type, Trek2-/-, and Trek1/2/Traak ${ }^{-/-}$mice, measured over six separate trials ( $n=11-18$ per group). A main effect of trial number was observed $\left[F_{(5,228)}=8.80, P<0.001\right]$; within-genotype, pair-wise comparisons are not shown on the plot. A main effect of genotype was not detected $\left[F_{(2,228)}=3.0, P=0.06\right]$, nor was there a significant interaction between trial and genotype $\left[F_{(10,228)}=0.8, P=0.62\right]$. Symbols: $* * *, * * * P<0.05,0.01$, and 0.001 , respectively, vs. wild-type. behaviors consistent with lower anxiety-related behavior (Simon et al., 1994).

Motor coordination was evaluated in wild-type, Trek $2^{-/-}$, and Trek1/2/Traak ${ }^{-/-}$mice using an accelerating rotarod test as described (Anderson et al., 2010). No effect of gender was observed in this task $\left[F_{(1,263)}=2.9, P=0.09\right]$; as such male and female data were pooled. No genotype-dependent differences were observed with respect to ability of the mice to learn the task, learning rate, or peak performance (Figure 1F).

\section{ANXIETY-RELATED BEHAVIOR}

While rotarod and open-field activity data indicated that Trek2 $2^{-/-}$and Trek1/2/Traak ${ }^{-/-}$mice do not exhibit gross deficiencies in motor activity or coordination, the reduced thigmotaxis observed in female Trek2-/- and Trek1/2/Traak ${ }^{-/}$mice argued that Trek channels may influence anxiety-related behavior. To gain additional insight into anxiety-related behavior in Trek $2^{-/-}$and Trek1/2/Traak ${ }^{-/-}$mice, we next examined performance in an elevated plus maze, an established measure of anxiety-related behavior (Lister, 1987). While Trek2-/- and
Trek1/2/Traak ${ }^{-/-}$mice tended to spend more time in the open arms (Figure 2A), and made more entries into the open arms of the maze (Figure 2B), differences were not significant, for either gender. Similarly, no genotype-dependent differences were observed in either male or female mice in terms of the time spent in closed arms (Figure 2C) or number of entries into the closed arms (Figure 2D).

We also tested animals in the light/dark box, an alternative measure of anxiety-related behavior (Bourin and Hascoet, 2003). In this task, animals are placed in a two-compartment chamber, one dark and the other brightly illuminated. Increased time spent in the light chamber is consistent with reduced anxiety-related behavior (Costall et al., 1989). As an influence of gender was previously observed in the open-field test, we again analyzed data from male and female subjects separately. Total time spent in the light compartment did not differ between genotypes in male or female mice (Figure 3A). Moreover, no gender or genotype differences were observed with respect to total distance traveled during the 10-min trial (not shown) or distance traveled in the light compartment (Figure 3B). 


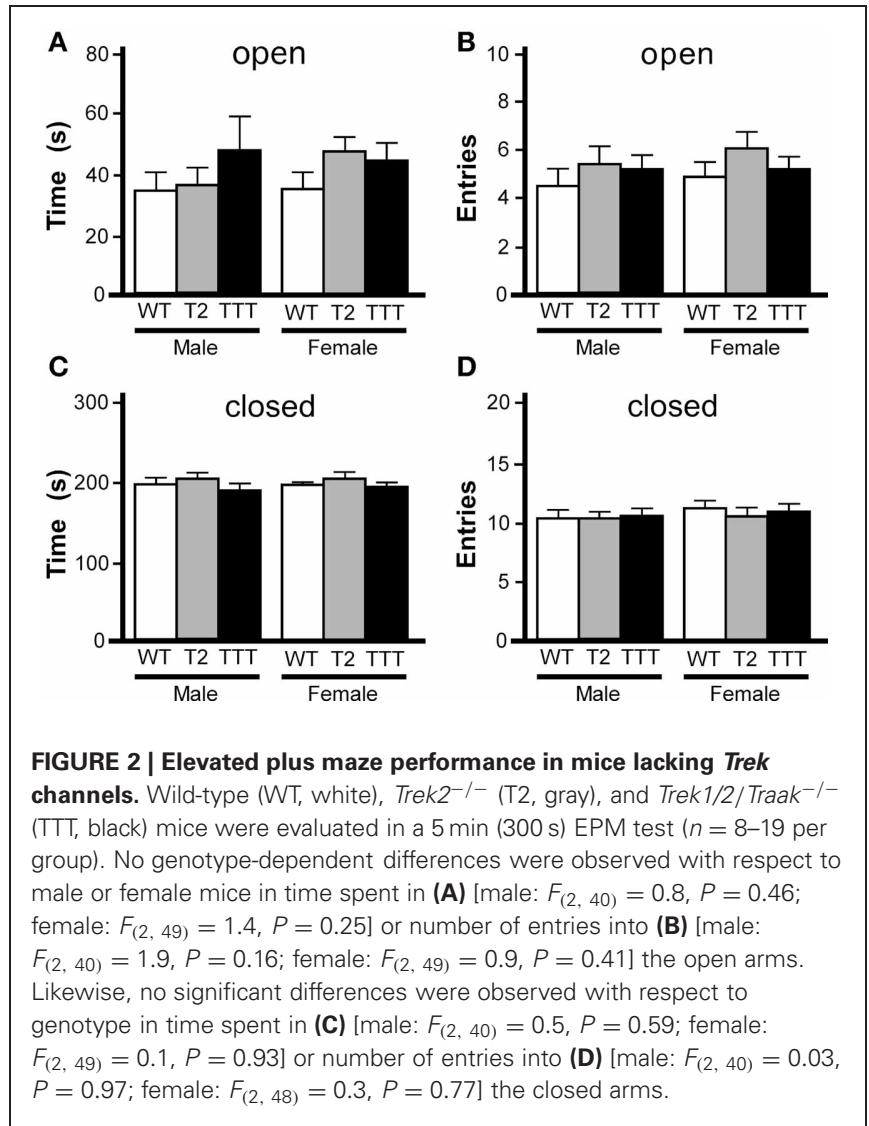

\section{LEARNING AND MEMORY}

To assess the learning and memory ability of Trek2 $2^{-/}$and Trek1/2/Traak ${ }^{-/-}$mice, we first tested animals in a contextual fear conditioning task. This $2 \mathrm{~d}$ test of Pavlovian learning involves the association of a painful stimulus (foot shock) with an environment (Rudy et al., 2004). The first session included three conditioning trials separate by $60 \mathrm{~s}$, each consisting of a $2 \mathrm{~s}(0.7 \mathrm{~mA})$ shock delivered after presentation of a $20 \mathrm{~s}$ light cue. The test day consisted of a 5 min re-exposure to the training environment and evaluation of freezing behavior. No effect of gender was observed in total time spent freezing $\left[F_{(1,29)}=2.8, P=0.11\right]$ or in the number of freezing episodes $\left[F_{(1,29)}=0.1, P=0.72\right]$; as such, data from male and female subjects were pooled. No genotypedependent differences were observed in total time spent freezing (Figure 4A) or in the number of freezing episodes (Figure 4B).

We next tested the effect of Trek ablation in the novel object recognition task, which has been used to assess working memory, anxiety, and preference for novelty in rodents (Dere et al., 2007). The task requires an animal to recognize and recall prior experience with a familiar object, and discriminate that object from a novel object. In our paradigm, mice were exposed to the openfield chamber for $60 \mathrm{~min}$ on the day prior to testing. On test day, mice were re-introduced to the open-field chamber for $30 \mathrm{~min}$, then again in two consecutive $10 \mathrm{~min}$ sessions incorporating an object (familiar), and finally in a 5-min test session where both the familiar object and a novel object were present in the field. The time spent exploring both objects were recorded during the
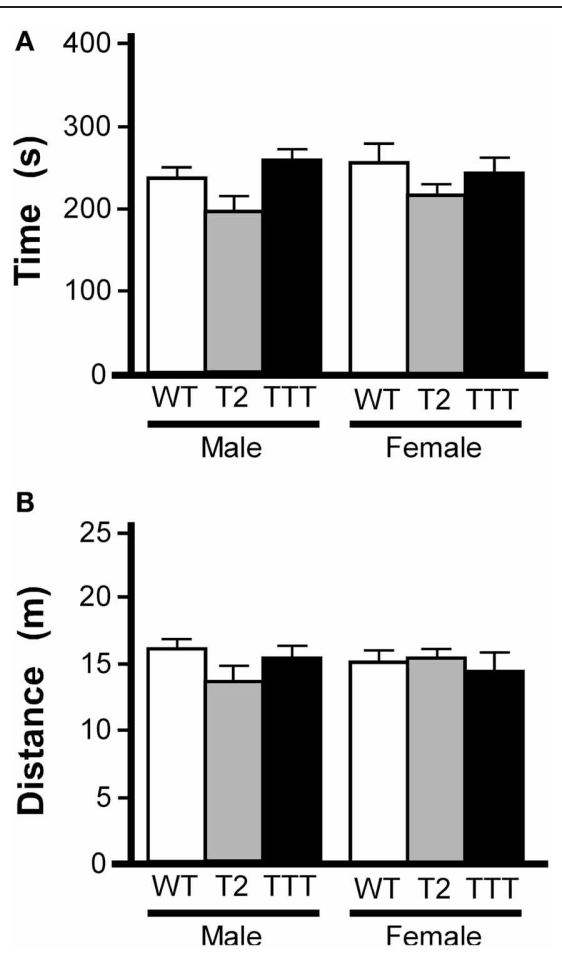

FIGURE 3 | Light/dark box behavior in mice lacking Trek channels. Wild-type (WT, white), Trek2-/- (T2, gray), and Trek1/2/Traak ${ }^{-/-}$ (TTT, black) mice were evaluated in a $10 \mathrm{~min}$ (600 s) light/dark box test ( $n=5-12$ per group). (A) Time spent in the light compartment; no genotype-dependent differences were observed for male $\left[F_{(2,22)}=2.7\right.$, $P=0.09]$ or female $\left[F_{(2,25)}=1.0, P=0.38\right]$ mice. (B) Distance traveled in the light compartment; no genotype-dependent differences were observed in male $\left[F_{(2,22)}=1.7, P=0.21\right]$ or female $\left[F_{(2,25)}=0.2, P=0.82\right]$ mice.

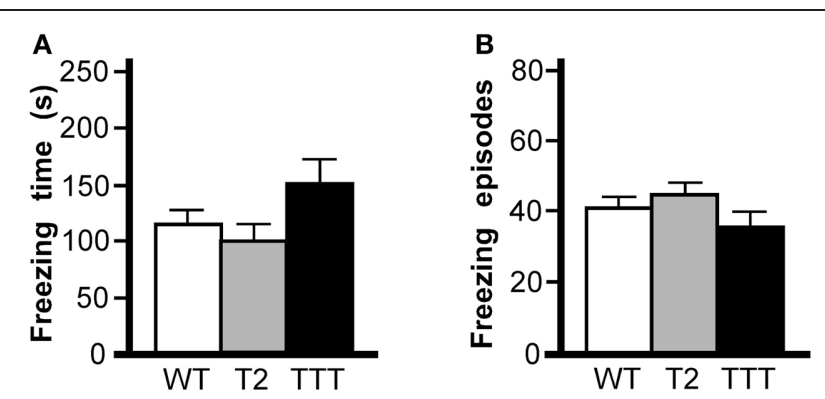

FIGURE 4 | Contextual fear conditioning in mice lacking Trek channels. Wild-type (WT, white), Trek2-/- (T2, gray), and Trek1/2/Traak-/- (TTT, black) mice were evaluated in $5 \mathrm{~min}(300 \mathrm{~s})$ contextual fear conditioning test ( $n=9-14$ per group). (A) Time spent freezing; no genotype-dependent differences were observed with respect to time spent freezing $\left[F_{(2,34)}=2.4, P=0.11\right]$. (B) Freezing episodes; no genotype-dependent differences were observed with respect to number of freezing episodes $\left[F_{(2,34)}=1.4, P=0.25\right]$.

test session. No effect of gender was observed for any parameter analyzed (time exploring novel object, $F_{(1,19)}=0.4, P=0.55$; time exploring familiar object, $F_{(1,19)}=0.8, P=0.39$; total time exploring objects, $F_{(1,19)}=0.1, P=0.78$; discrimination ratio, 
$\left.F_{(1,19)}=2.3, P=0.14\right)$, and as such, data from male and female subjects were pooled. The total time spent exploring both the familiar (Figure 5A) and novel (Figure 5B) objects during the test session were not different across genotypes, nor was the total time spent exploring both objects (Figure 5C). And, while all genotypes showed a preference for the novel object over the familiar, no differences were observed with respect to genotype in this regard (Figure 5D).

\section{REWARD-RELATED BEHAVIOR}

Normal opioid-induced motor stimulation and CPP require activation of mu opioid receptors in midbrain structures, including the ventral tegmental area (Bozarth and Wise, 1986; Bozarth, 1987; Kalivas and Duffy, 1987; Latimer et al., 1987). Mu opioid receptors are metabotropic ( $\mathrm{G}$ protein-coupled) receptors linked to the $G_{i / o}$ subclass of $G$ proteins. Previous studies have indicated that both Trek 1 and Trek 2 can be activated by GPCRs linked to $\mathrm{G}_{\mathrm{i} / \mathrm{o}} \mathrm{G}$ proteins (Fink et al., 1996; Patel et al., 1998; Lesage et al., 2000; Murbartian et al., 2005; Deng et al., 2009; Xiao et al., 2009), and both channels are expressed in the mouse midbrain (Lein et al., 2007). Accordingly, we evaluated the impact of Trek ablation on the motor-stimulatory and rewarding effect of morphine, the prototypical mu opioid receptor agonist. Morphine doses higher than $30 \mathrm{mg} / \mathrm{kg}$ yielded elevated stereotypic movements and reduced overall activity levels in wild-type mice
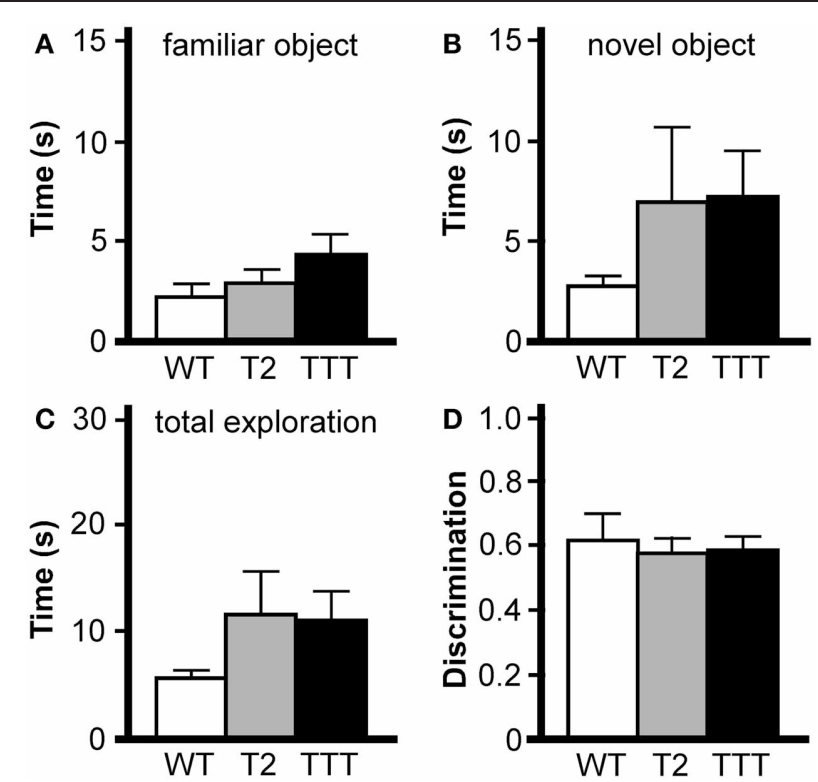

FIGURE 5 | Novel object recognition in mice lacking Trek channels. Wild-type (WT, white), Trek2-/- (T2, gray), and Trek1/2/Traak-1-

(TTT, black) mice were evaluated in a novel object recognition task ( $n=7-9$ per group). No genotype-dependent differences were observed in terms of the amount of time spent during a $5 \mathrm{~min}(300 \mathrm{~s})$ test session interacting with the familiar object $(\mathbf{A})\left[F_{(2,22)}=1.7, P=0.21\right]$, time spent interacting with the novel object $(\mathbf{B})\left[F_{(2,22)}=1.0, P=0.39\right]$, total time interacting with the familiar and novel object (C) $\left[F_{(2,22)}=1.2, P=0.31\right]$, or in object discrimination ratio (D) $\left[F_{(2,22)}=0.1, P=0.87\right]$, defined as the ratio of time spent exploring the novel object to the total time spent exploring both objects [time novel $_{\text {/ }} /$ time $_{\text {familiar }}+$ time $\left._{\text {novel }}\right)$ ]. (not shown), and thus, $30 \mathrm{mg} / \mathrm{kg}$ morphine was selected as the maximal dose in this study. No effect of gender was observed in this task $\left[F_{(1,114)}<0.001, P=0.98\right]$; as such, data from male and female subjects were pooled. Systemic morphine administration stimulated motor activity in a dose-dependent manner in all genotypes (Figure 6A). While no difference between genotypes was observed at the lowest morphine doses evaluated $(3$ and $10 \mathrm{mg} / \mathrm{kg})$, Trek1/2/Traak ${ }^{-/-}$mice exhibited less morphine-induced motor activity at the $30 \mathrm{mg} / \mathrm{kg}$ dose.

Morphine-induced CPP was analyzed in wild-type, Trek2-/and Trek1/2/Traak Th $^{-1}$ mice using a two-compartment chamber. On Day 1, mice were allowed to explore both sides of the chamber during a $15 \mathrm{~min}$ session, and time spent on each side of the chamber was recorded. Over the next 3 days, animals were subjected to conditioning sessions where saline (AM session) or

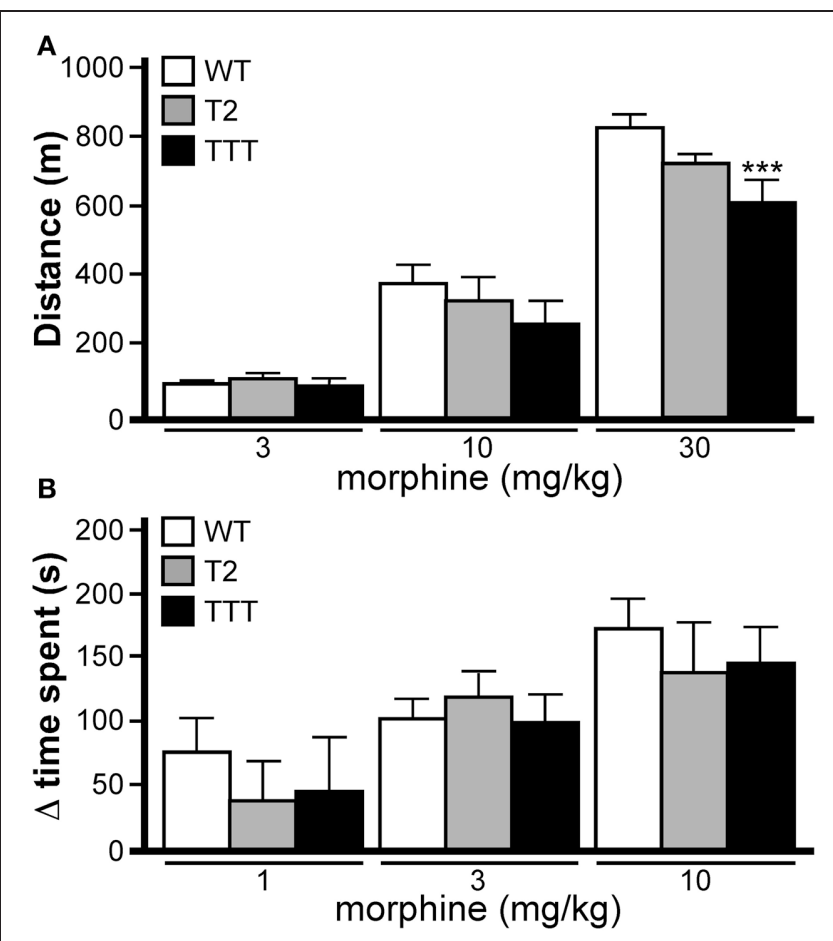

FIGURE 6 | Opioid-induced motor activity and reward in mice lacking Trek channels. (A) Morphine-induced locomotor activity was measured during a 60 min session in wild-type (WT, white), Trek2 $2^{-/-}$(T2, gray), and Trek 1/2/Traak ${ }^{-/-}$(TTT, black) mice ( $n=12-16$ per group). Significant main effects of morphine dose $\left[F_{(3,144)}=250.6, P<0.0001\right]$ and genotype $\left[F_{(2,144)}=4.6, P<0.05\right]$ were observed, as well as a dose $\times$ genotype interaction $\left[F_{(6,114)}=2.5, P<0.05\right]$. While no significant differences were observed between genotypes at either the $3 \mathrm{mg} / \mathrm{kg}$ or $10 \mathrm{mg} / \mathrm{kg}$ doses, Trek $1 / 2 /$ Traak $^{-/-}$showed a slightly blunted response to $30 \mathrm{mg} / \mathrm{kg}$ morphine as compared to wild-type controls. (B) Morphine-induced CPP was measured in wild-type ( $n=10-15 /$ dose), Trek2 ${ }^{-1-}(n=7-9 /$ dose), and Trek $1 / 2 /$ Traak $^{-1-}(n=6-7 /$ dose $)$ mice using a standard CPP test. While a significant main effect of morphine dose was observed $\left[F_{(2,73)}=9.0\right.$, $P<0.001]$, there was no main effect of genotype $\left[F_{(2,73)}=0.5, P=0.59\right]$ or dose $x$ genotype interaction $\left[F_{(4,73)}=0.32, P=0.86\right]$. No genotype-dependent differences were observed in morphine-induced CPP, as measured by calculating the change in time spent ( $\Delta$ time spent) in the drug-paired side from Day 1-5. In panels $\mathbf{A}$ and $\mathbf{B}$, only within-dose pair-wise comparisons are highlighted. Symbols: ${ }^{* * *} P<0.01$, vs. wild-type. 
morphine (1, 3, or $10 \mathrm{mg} / \mathrm{kg}$; PM session) was administered systemically prior to confinement in a defined (counterbalanced) side of the chamber. In a pilot study involving wild-type mice, no difference in the magnitude of the morphine-induced CPP was observed for 10 and $30 \mathrm{mg} / \mathrm{kg}$ morphine doses $\left[t_{22}=0.2\right.$, $P=0.9]$. Accordingly, wild-type and Trek ${ }^{-/-}$mice were challenged with $10 \mathrm{mg} / \mathrm{kg}$ morphine as the highest dose in this test. No effect of gender was observed $\left[F_{(1,64)}=0.1, P=0.81\right]$; as such, male and female data was pooled. A dose-dependent increase in time spent in the drug-paired side was observed for all genotypes, and the magnitude of the morphine-induced CPP measured in Trek $2^{-/-}$and Trek1/2/Traak ${ }^{-/-}$mice was no different from wild-type controls at any dose tested (Figure 6B).

\section{DISCUSSION}

Recent work by our laboratory, as well as in situ hybridization data collected by the Allen Institute for Brain Research (Lein et al., 2007), suggests a widespread distribution of Trek2 mRNA in the mouse CNS. Accordingly, and given the well-documented and broad expression of Trek1 and Traak in the rodent CNS (Medhurst et al., 2001; Talley et al., 2001; Gu et al., 2002), one might predict that Trek channel activity influences neurophysiology and behavior in a broad manner. The primary goal of this study was to begin assessing the impact of Trek ablation on mouse behavior, using a representative battery of behavioral paradigms.

Trek gene ablation exerted little influence on motor activity or coordination. A significant difference, and clear interaction between genotype and gender, was observed in anxietyrelated behavior in the open-field. Female Trek2-/- and Trek1/2/Traak ${ }^{-/-}$mice exhibited significantly reduced thigmotaxis and increased time spent in the center of the open-field. While many brain regions have been linked to anxiety, the hippocampus and amygdala are key anatomic loci for anxiety-related behavior (Menard and Treit, 1999; Canteras et al., 2010). In this regard, the relatively high level of Trek 2 mRNA observed in both structures in the mouse and human may be relevant (Medhurst et al., 2001; Lein et al., 2007; Mirkovic and Wickman, 2011). However, Trek2-/- and Trek1/2/Traak ${ }^{-/-}$mice performed similar to wild-type controls in the elevated plus maze and light/dark box tests, other established tests of anxiety-related behavior. Such discrepancies within anxiety-related behavioral paradigms have been reported for other mutant mouse strains (Salas et al., 2003; Bhatnagar et al., 2004; Lau et al., 2008), and argue that any influence of Trek channels on anxiety-related behavior is modest and/or not uniform.

Recent work has shown that Trek channels mediate, in part, the inhibitory effect of $\mathrm{GABA}_{\mathrm{B}}$ receptor stimulation on neurons in the hippocampus and entorhinal cortex (Deng et al., 2009; Sandoz et al., 2012), and have suggested a role for Trek channels in learning and memory (Deng et al., 2009). We, however, observed no influence of Trek ablation on learning and memory, as assessed using novel object recognition and contextual fear conditioning tasks. One concern in studies involving these and other standard paradigms is whether underlying abnormalities in sensory perception influence behavioral outcomes. And while our experience did not reveal gross deficiencies in vision, hearing, or touch in Trek ${ }^{-/-}$mice, we cannot exclude the possibility that subtle differences exist that impacted their performance in some of the chosen tasks. For example, previous studies have revealed decreased pain thresholds with Trek1 $1^{-/}$and Traak ${ }^{-/-}$mice (Alloui et al., 2006; Noel et al., 2009). As such, the behavior of Trek $^{-/-}$mice in paradigms that involve an aversive stimulus, such as a foot shock (e.g., contextual fear conditioning), could reflect altered sensitivity to the aversive stimulus, altered associative learning processes and/or memory recall, or a mixture of influences. Nevertheless, the simplest interpretation of our fear conditioning and novel object recognition data is that Trek channels exert little if any significant influence over associative learning processes.

Trek channels are activated by receptors linked to $G_{i / o} G$ proteins in a process thought to involve inhibition of cAMP production and a decrease in PKA-dependent phosphorylation (Patel et al., 1998; Lesage et al., 2000; Murbartian et al., 2005; Deng et al., 2009; Xiao et al., 2009). Opioids such as morphine bind to $\mathrm{G}_{\mathrm{i} / \mathrm{o}}$ coupled receptors expressed in the midbrain, leading to increased motor activity and CPP (Bozarth and Wise, 1986; Bozarth, 1987; Kalivas and Duffy, 1987; Latimer et al., 1987). As Trek channels are expressed in the mouse midbrain (Lein et al., 2007), we probed for a contribution of Trek channels to opioidinduced reward-related behavior. Interestingly, Trek1/2/Traak ${ }^{-/-}$ mice did display a blunted motor-stimulatory response to the highest dose of morphine tested. As Trek $2^{-/-}$mice behaved normally in this task, the phenotype is most likely attributable to the loss of Trek1, since Traak channels are not modulated by G protein signaling (Fink et al., 1998; Maingret et al., 2000; Kim et al., 2001). In contrast, we found no impact of Trek channel ablation on morphine-induced CPP. Thus, consistent with our assessment of anxiety-related behavior in Trek $k^{-/-}$mice, any contribution of Trek channels to opioid-induced reward-related behavior appear to be modest and paradigm-dependent.

While the broad CNS distribution of Trek channels suggests that this channel family makes significant contributions to many behaviors, we found few neurobehavioral phenotypes in Trek $^{-/-}$mice in this study. An important consideration for any study involving constitutive gene ablation is that subtle molecular and/or developmental compensation might mask the influence of a gene or genes on complex behaviors. Accordingly, data from studies involving constitutive knockout mice should be interpreted with caution until corroborated by data obtained via alternative approaches. This is particularly true for studies such as this, where the behavior of multiple congenic mutant lines is compared to a single wild-type control group rather than to same-sex wildtype littermates. Nevertheless, the simplest interpretation of the available data is that the neurobehavioral influence of Trek channels is relatively modest or non-existent, at least in the context of the behaviors evaluated in this study.

One intriguing scenario that might reconcile the broad CNS distribution of Trek channels with their modest impact on behavior is that Trek channel activity is low under normal conditions, becoming evident and impactful only under certain circumstances, such as ischemia (Heurteaux et al., 2004; Buckler and Honore, 2005; Caley et al., 2005; Wang et al., 2012). Indeed, Trek channels are activated by polyunsaturated fatty acids (Patel et al., 1998; Lesage et al., 2000; Maingret et al., 2000), intracellular 
acidification (Maingret et al., 1999; Lesage et al., 2000; Kim et al., 2001), and membrane stretch (Patel et al., 1998; Bang et al., 2000; Lesage et al., 2000), and all three of these influences are triggered by cerebral ischemia. Moreover, Trek1 $1^{-/}$mice show enhanced sensitivity to ischemia (Heurteaux et al., 2004), and Trek1 is up-regulated after focal ischemia (Wang et al., 2012). Recently, Trek2 expression was shown to increase after exposure to ischemic conditions (Kucheryavykh et al., 2009). Thus, future studies exploring the neurophysiological relevance of Trek2-containing channels under ischemic conditions will be important.

\section{REFERENCES}

Alloui, A., Zimmermann, K., Mamet, J., Duprat, F., Noel, J., Chemin, J., Guy, N., Blondeau, N., Voilley, N., Rubat-Coudert, C., Borsotto, M., Romey, G., Heurteaux, C., Reeh, P., Eschalier, A., and Lazdunski, M. (2006). TREK-1, a $\mathrm{K}^{+}$channel involved in polymodal pain perception. $E M B O$ J. 25, 2368-2376.

Anderson, G. R., Cao, Y., Davidson, S., Truong, H. V., Pravetoni, M., Thomas, M. J., Wickman, K., Giesler, G. J. Jr., and Martemyanov, K. A. (2010). R7BP complexes with RGS9-2 and RGS7 in the striatum differentially control motor learning and locomotor responses to cocaine. Neuropsychopharmacology 35, 1040-1050.

Bang, H., Kim, Y., and Kim, D. (2000). TREK-2, a new member of the mechanosensitive tandem-pore $\mathrm{K}^{+}$ channel family. J. Biol. Chem. 275, 17412-17419.

Bhatnagar, S., Sun, L. M., Raber, J., Maren, S., Julius, D., and Dallman, M. F. (2004). Changes in anxiety-related behaviors and hypothalamic-pituitary-adrenal activity in mice lacking the 5-HT3A receptor. Physiol. Behav. 81, 545-555.

Bockenhauer, D., Zilberberg, N., and Goldstein, S. A. (2001). KCNK2, reversible conversion of a hippocampal potassium leak into a voltage-dependent channel. Nat. Neurosci. 4, 486-491.

Bourin, M., and Hascoet, M. (2003). The mouse light/dark box test. Eur. J. Pharmacol. 463, 55-65.

Bozarth, M. A. (1987). Neuroanatomical boundaries of the reward-relevant opiate-receptor field in the ventral tegmental area as mapped by the conditioned place preference method in rats. Brain Res. 414, 77-84.

Bozarth, M. A., and Wise, R. A. (1986). Involvement of the ventral tegmental dopamine system in opioid and psychomotor stimulant reinforcement. NIDA Res. Monogr. 67, 190-196.

Buckler, K. J., and Honore, E. (2005). The lipid-activated two-pore domain $\mathrm{K}^{+}$channel TREK-1 is resistant to hypoxia: implication for ischaemic neuroprotection. J. Physiol. 562, 213-222.

Caley, A. J., Gruss, M., and Franks, N. P. (2005). The effects of hypoxia on the modulation of human TREK-1 potassium channels. J. Physiol. 562, 205-212.

Canteras, N. S., Resstel, L. B., Bertoglio, L. J., Carobrez Ade, P., and Guimaraes, F. S. (2010). Neuroanatomy of anxiety. Curr. Top. Behav. Neurosci. 2, 77-96. Naylor, R. J., and Tomkins, D. M. (1989). Exploration of mice in a black and white test box: validation as a model of anxiety. Pharmacol. Biochem. Behav. 32, 777-785.

Deng, P. Y., Xiao, Z., Yang, C., Rojanathammanee, L., Grisanti, L., Watt, J., Geiger, J. D., Liu, R., Porter, J. E., and Lei, S. (2009). $\mathrm{GABA}_{\mathrm{B}}$ receptor activation inhibits neuronal excitability and spatial learning in the entorhinal cortex by activating TREK- $2 \mathrm{~K}^{+}$channels. Neuron 63, 230-243.

Dere, E., Huston, J. P., and De Souza Silva, M. A. (2007). The pharmacology, neuroanatomy and neurogenetics of one-trial object recognition in rodents. Neurosci. Biobehav. Rev. 31, 673-704.

Enyedi, P., and Czirjak, G. (2010). Molecular background of leak $\mathrm{K}^{+}$ currents: two-pore domain potassium channels. Physiol. Rev. 90, 559-605. R., Romey, G., Heurteaux, C., and Lazdunski, M. (1996). Cloning, functional expression and brain localization of a novel unconventional outward rectifier $\mathrm{K}^{+}$channel. EMBO J. 15, 6854-6862.

Fink, M., Lesage, F., Duprat, F., Heurteaux, C., Reyes, R., Fosset, M., and Lazdunski, M. (1998). A
Costall, B., Jones, B. J., Kelly, M. E.,

Fink, M., Duprat, F., Lesage, F., Reyes,

\section{ACKNOWLEDGMENTS}

The authors would like to thank Desirae Haluk and Lydia Kotecki for assistance with the conditioned place preference task, Daniel Bomsta and Benjamin Yun for assistance with the elevated plus maze, and Daniele Young for maintenance of the mouse colonies. This work was supported by NIH grants MH061933 (Kevin Wickman), DA011806 (Kevin Wickman), DA029343 (Kevin Wickman), and T32 DA07234 (Kelsey Mirkovic), and a grant from the Fondation pour la Recherche Médicale (Equipe labellisée FRM 2007; Florian Lesage).

neuronal two $\mathrm{P}$ domain $\mathrm{K}^{+}$channel stimulated by arachidonic acid and polyunsaturated fatty acids. EMBO J. 17, 3297-3308.

Gierten, J., Hassel, D., Schweizer, P. A., Becker, R., Katus, H. A., and Thomas, D. (2012). Identification and functional characterization of zebrafish K(2P)10.1 (TREK2) twopore-domain $\mathrm{K}^{+}$channels. Biochim. Biophys. Acta 1818, 33-41.

Gu, W., Schlichthorl, G., Hirsch, J. R. Engels, H., Karschin, C., Karschin, A., Derst, C., Steinlein, O. K., and Daut, J. (2002). Expression pattern and functional characteristics of two novel splice variants of the two-pore-domain potassium channel TREK-2. J. Physiol. 539, 657-668.

Guyon, A., Tardy, M. P., Rovere, C., Nahon, J. L., Barhanin, J., and Lesage, F. (2009). Glucose inhibition persists in hypothalamic neurons lacking tandem-pore $\mathrm{K}^{+}$channels. J. Neurosci. 29, 2528-2533.

Heurteaux, C., Guy, N., Laigle, C., Blondeau, N., Duprat, F., Mazzuca, M., Lang-Lazdunski, L., Widmann, C., Zanzouri, M., Romey, G., and Lazdunski, M. (2004). TREK-1, a $\mathrm{K}^{+}$channel involved in neuroprotection and general anesthesia. EMBO J. 23, 2684-2695.

Heurteaux, C., Lucas, G., Guy, N., El Yacoubi, M., Thummler, S. Peng, X. D., Noble, F., Blondeau, N., Widmann, C., Borsotto, M., Gobbi, G., Vaugeois, J. M., Debonnel, G., and Lazdunski, M. (2006). Deletion of the background potassium channel TREK-1 results in a depression-resistant phenotype. Nat. Neurosci. 9, 1134-1141.

Kalivas, P. W., and Duffy, P. (1987). Sensitization to repeated morphine injection in the rat: possible involvement of A10 dopamine neurons. J. Pharmacol. Exp. Ther. 241, 204-212.

Kang, D., Choe, C., and Kim, D. (2005). Thermosensitivity of the two-pore domain $\mathrm{K}^{+}$channels TREK-2 and TRAAK. J. Physiol. 564, 103-116.
Kim, Y., Gnatenco, C., Bang, H., and Kim, D. (2001). Localization of TREK-2 $\mathrm{K}^{+}$channel domains that regulate channel kinetics and sensitivity to pressure, fatty acids and $\mathrm{pH}_{\mathrm{i}}$. Pflugers Arch. 442, 952-960.

Kucheryavykh, L. Y., Kucheryavykh, Y. V., Inyushin, M., Shuba, Y. M., Sanabria, P., Cubano, L. A., Skatchkov, S. N., and Eaton, M. J. (2009). Ischemia increases TREK2 channel expression in astrocytes: relevance to glutamate clearance. Open Neurosci. J. 3, 40-47.

Latimer, L. G., Duffy, P., and Kalivas, P. W. (1987). Mu opioid receptor involvement in enkephalin activation of dopamine neurons in the ventral tegmental area. J. Pharmacol. Exp. Ther. 241, 328-337.

Lau, A. A., Crawley, A. C., Hopwood, J. J., and Hemsley, K. M. (2008). Open field locomotor activity and anxiety-related behaviors in mucopolysaccharidosis type IIIA mice. Behav. Brain Res. 191, 130-136.

Lein, E. S., Hawrylycz, M. J., Ao, N., Ayres, M., Bensinger, A., Bernard, A., Boe, A. F., Boguski, M. S., Brockway, K. S., Byrnes, E. J., Chen, L., Chen, T. M., Chin, M. C., Chong, J., Crook, B. E., Czaplinska, A., Dang, C. N., Datta, S., Dee, N. R., Desaki, A. L., Desta, T., Diep, E., Dolbeare, T. A., Donelan, M. J., Dong, H. W., Dougherty, J. G., Duncan, B. J., Ebbert, A. J., Eichele, G., Estin, L. K., Faber, C., Facer, B. A., Fields, R., Fischer, S. R. Fliss, T. P., Frensley, C., Gates, S. N., Glattfelder, K. J., Halverson, K. R., Hart, M. R., Hohmann, J. G., Howell, M. P., Jeung, D. P., Johnson, R. A., Karr, P. T., Kawal, R., Kidney, J. M., Knapik, R. H., Kuan, C. L., Lake, J. H., Laramee, A. R. Larsen, K. D., Lau, C., Lemon, T. A., Liang, A. J., Liu, Y., Luong, L. T., Michaels, J., Morgan, J. J., Morgan, R. J., Mortrud, M. T., Mosqueda, N. F., Ng, L. L., Ng, R., Orta, G. J., Overly, C. C., Pak, T. H. Parry, S. E., Pathak, S. D., Pearson, 
O. C., Puchalski, R. B., Riley, Z. L., Rockett, H. R., Rowland, S. A., Royall, J. J., Ruiz, M. J., Sarno, N. R., Schaffnit, K., Shapovalova, N. V., Sivisay, T., Slaughterbeck, C. R., Smith, S. C., Smith, K. A., Smith, B. I., Sodt, A. J., Stewart, N. N., Stumpf, K. R., Sunkin, S. M., Sutram, M., Tam, A., Teemer, C. D., Thaller, C., Thompson, C. L., Varnam, L. R., Visel, A., Whitlock, R. M., Wohnoutka, P. E., Wolkey, C. K., Wong, V. Y., Wood, M., Yaylaoglu, M. B., Young, R. C., Youngstrom, B. L., Yuan, X. F., Zhang, B., Zwingman, T. A., and Jones, A. R. (2007). Genome-wide atlas of gene expression in the adult mouse brain. Nature 445, 168-176.

Lesage, F., Terrenoire, C., Romey, G., and Lazdunski, M. (2000). Human TREK2, a 2P domain mechanosensitive $\mathrm{K}^{+}$channel with multiple regulations by polyunsaturated fatty acids, lysophospholipids, and $\mathrm{G}_{\mathrm{s}}, \mathrm{G}_{\mathrm{i}}$, and $\mathrm{G}_{\mathrm{q}}$ protein-coupled receptors. J. Biol. Chem. 275, 28398-28405.

Liou, Y. J., Chen, T. J., Tsai, S. J., Yu, Y. W., Cheng, C. Y., and Hong, C. J. (2009). Support for the involvement of the KCNK2 gene in major depressive disorder and response to antidepressant treatment. Pharmacogenet. Genomics 19, 735-741.

Lister, R. G. (1987). The use of a plusmaze to measure anxiety in the mouse. Psychopharmacology (Berl.) 92, 180-185.

Maingret, F., Lauritzen, I., Patel, A. J., Heurteaux, C., Reyes, R., Lesage, F., Lazdunski, M., and Honore, E. (2000). TREK-1 is a heat-activated background $\mathrm{K}^{+}$channel. EMBO J. 19, 2483-2491.

Maingret, F., Patel, A. J., Lesage, F., Lazdunski, M., and Honore, E. (1999). Mechano- or acid stimulation, two interactive modes of activation of the TREK-1 potassium channel. J. Biol. Chem. 274, 26691-26696

Maingret, F., Patel, A. J., Lesage, F., Lazdunski, M., and Honore, E.
(2000). Lysophospholipids open the two-pore domain mechano-gated $\mathrm{K}^{+}$channels TREK-1 and TRAAK. J. Biol. Chem. 275, 10128-10133.

Mazella, J., Petrault, O., Lucas, G., Deval, E., Beraud-Dufour, S., Gandin, C., El-Yacoubi, M., Widmann, C., Guyon, A., Chevet, E., Taouji, S., Conductier, G., Corinus, A., Coppola, T., Gobbi, G., Nahon, J. L., Heurteaux, C., and Borsotto, M. (2010). Spadin, a sortilin-derived peptide, targeting rodent TREK-1 channels: a new concept in the antidepressant drug design. PLoS Biol. 8:e1000355. doi: 10.1371/journal.pbio.1000355

Medhurst, A. D., Rennie, G., Chapman, C. G., Meadows, H., Duckworth, M. D., Kelsell, R. E., Gloger, I. I., and Pangalos, M. N. (2001). Distribution analysis of human two pore domain potassium channels in tissues of the central nervous system and periphery. Brain Res. Mol. Brain Res. 86, 101-114.

Menard, J., and Treit, D. (1999). Effects of centrally administered anxiolytic compounds in animal models of anxiety. Neurosci. Biobehav. Rev. 23, 591-613.

Mirkovic, K., and Wickman, K. (2011). Identification and characterization of alternative splice variants of the mouse Trek2/Kcnk10 gene. Neuroscience 194, 11-18.

Moha ou Maati, H., Peyronnet, R., Devader, C., Veyssiere, J., Labbal, F., Gandin, C., Mazella, J., Heurteaux, C., and Borsotto, M. (2011). A human TREK-1/HEK cell line: a highly efficient screening tool for drug development in neurological diseases. PLOS ONE 6:e25602. doi: 10.1371/journal.pone.0025602

Moha Ou Maati, H., Veyssiere, J., Labbal, F., Coppola, T., Gandin, C., Widmann, C., Mazella, J., Heurteaux, C., and Borsotto, M. (2012). Spadin as a new antidepressant: absence of TREK-1-related side effects. Neuropharmacology 62, 278-288.

Murbartian, J., Lei, Q., Sando, J. J., and Bayliss, D. A. (2005). Sequential phosphorylation mediates receptorand kinase-induced inhibition of TREK-1 background potassium channels. J. Biol. Chem. 280, 30175-30184.

Noel, J., Zimmermann, K., Busserolles, J., Deval, E., Alloui, A., Diochot, S., Guy, N., Borsotto, M., Reeh, P., Eschalier, A., and Lazdunski, M. (2009). The mechano-activated $\mathrm{K}^{+}$ channels TRAAK and TREK-1 control both warm and cold perception. EMBO J. 28, 1308-1318.

Patel, A. J., Honore, E., Maingret, F. Lesage, F., Fink, M., Duprat, F. and Lazdunski, M. (1998). A mammalian two pore domain mechanogated S-like $\mathrm{K}^{+}$channel. EMBO J. 17, 4283-4290.

Perlis, R. H., Moorjani, P., Fagerness, J., Purcell, S., Trivedi, M. H., Fava, M., Rush, A. J., and Smoller, J. W. (2008). Pharmacogenetic analysis of genes implicated in rodent models of antidepressant response: association of TREK1 and treatment resistance in the $\operatorname{STAR}\left(^{*}\right) \mathrm{D}$ study. Neuropsychopharmacology 33 , 2810-2819.

Pravetoni, M., and Wickman, K. (2008). Behavioral characterization of mice lacking GIRK/Kir3 channel subunits. Genes Brain Behav. 7, 523-531.

Rudy, J. W., Huff, N. C., and MatusAmat, P. (2004). Understanding contextual fear conditioning: insights from a two-process model. Neurosci. Biobehav. Rev. 28, 675-685.

Salas, R., Pieri, F., Fung, B., Dani, J. A., and De Biasi, M. (2003). Altered anxiety-related responses in mutant mice lacking the beta4 subunit of the nicotinic receptor. J. Neurosci. 23, 6255-6263.

Sandoz, G., Levitz, J., Kramer, R. H. and Isacoff, E. Y. (2012). Optical control of endogenous proteins with a photoswitchable conditional subunit reveals a role for TREK1 in GABA $_{B}$ signaling. Neuron 74 1005-1014.

Simon, P., Dupuis, R., and Costentin, J. (1994). Thigmotaxis as an index of anxiety in mice. Influence of dopaminergic transmissions. Behav. Brain Res. 61, 59-64.

Talley, E. M., Solorzano, G., Lei, Q., Kim, D., and Bayliss, D. A. (2001) CNS distribution of members of the two-pore-domain (KCNK) potassium channel family. J. Neurosci. 21, 7491-7505.

Wang, M., Song, J., Xiao, W., Yang, L., Yuan, J., Wang, W., Yu, Z., and Xie, M. (2012). Changes in lipidsensitive two-pore domain potassium channel TREK-1 expression and its involvement in astrogliosis following cerebral ischemia in rats. J. Mol. Neurosci. 46, 384-392.

Xiao, Z., Deng, P. Y., Rojanathammanee, L., Yang, C., Grisanti, L., Permpoonputtana, K., Weinshenker, D., Doze, V. A., Porter, J. E., and Lei, S. (2009). Noradrenergic depression of neuronal excitability in the entorhinal cortex via activation of TREK-2 $\mathrm{K}^{+}$channels. J. Biol. Chem. 284, 10980-10991.

Conflict of Interest Statement: The authors declare that the research was conducted in the absence of any commercial or financial relationships that could be construed as a potential conflict of interest.

Received: 27 June 2012; accepted: 23 August 2012; published online: 07 September 2012.

Citation: Mirkovic K, Palmersheim J, Lesage F and Wickman K (2012) Behavioral characterization of mice lacking Trek channels. Front. Behav. Neurosci. 6:60. doi: 10.3389/fnbeh. 2012.00060

Copyright (C) 2012 Mirkovic, Palmersheim, Lesage and Wickman. This is an open-access article distributed under the terms of the Creative Commons Attribution License, which permits use, distribution and reproduction in other forums, provided the original authors and source are credited and subject to any copyright notices concerning any third-party graphics etc. 